\title{
Computed tomographic versus radiographic assessment of the visibility and features of subchondral cystic lesions in equine limbs
}

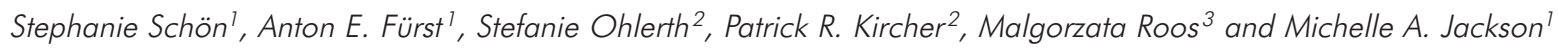 \\ ${ }^{1}$ Equine Department, Vetsuisse Faculty, University of Zurich, Switzerland \\ 2 Clinic of Diagnostic Imaging, Department of Small Animals, Vetsuisse Faculty, University of Zurich, Switzerland \\ ${ }^{3}$ Department of Biostatistics, Epidemiology, Biostatistics and Prevention Institute, Medical Faculty, University of Zurich, Switzerland
}

\begin{abstract}
Summary: Subchondral cystic lesions (SCLs) are common in horses and often cause lameness and they are commonly diagnosed by radiography. This study compares radiographic and computed tomographic (CT) features of subchondral cystic lesions in horses. It was hypothesized, that CT has a superior diagnostic value for the assessment of the features of SCLs compared to radiography. Horses diagnosed with one or two SCLs in CT and a radiographic study of the affected bone were included. SCLs were evaluated on radiographs and CT for location, size, shape, homogeneity, continuity of the subchondral bone, peripheral sclerosis, presence of a fissure, osteoarthritis (OA) and periostitis. Vascular channels were only assessed with CT. Subsequently, radiographic findings were compared to CT. Forty-two SCLs in a total of 32 horses were included in the study. Radiographic visibility of SCLs diagnosed with CT was $79 \%$ (95\% Cl: 0.64 to 0.88$)$. In joints with two SCLs, the second cystic lesion was more often missed radiographically $(p=0.014)$. A discontinuous subchondral bone was evident in CT in 40 of 42 SCLs whereas it was suspected in only 23 of 33 radiographically diagnosed SCLs. With CT, fissures were more commonly diagnosed and in $16 \mathrm{SCLs}$, vascular channels were identified. SCLs with fissures showed more periostitis with CT ( $p=0.01$ ). Radiographically missed SCLs presented less peripheral sclerosis in CT $(p=0.023)$. Intermodality agreement was borderline good $(\kappa=0.60-0.66)$ for location (proximal, distal; lateral, medial, midsagittal), $\mathrm{OA}$ and periostitis, borderline moderate for presence of a fissure $(\kappa=0.42)$, fair for homogeneity $(\kappa=0.35)$, and only poor for location (dorsal, central, palmar/plantar), shape, peripheral sclerosis and continuity of the subchondral bone $(\kappa=0.06-0.18)$. This study highlights the advantages of CT for the characterization of SCLs in horses. Vascular channels appear to be a frequent finding.
\end{abstract}

Keywords: subchondral cystic lesions (SCLs), equine limbs, computed tomography (CT), subchondral bone, fissures, vascular channels

Citation: Schön S., Fürst A. E., Ohlerth S., Kircher P. R., Roos M., Jackson M. A. (2017) Computed tomographic versus radiographic assessment of the visibility and features of subchondral cystic lesions in equine limbs. Pferdeheilkunde 33, 256-262; DOI 10.21836/PEM 20170306

Correspondence: Stephanie Schön, Equine Department, Vetsuisse Faculty, University of Zurich, Winterthurerstrasse 260, 8057 Zurich, Switzerland; E-mail: sschoen@vetclinics.uzh.ch

\section{Introduction}

Subchondral cystic lesions (SCLs) are common in horses and often cause lameness (Fürst et al. 1997, Garcia-Lopez et al. 2004). They are most frequently found in the medial femoral condyle (45.8\%), phalanges (26.2\%) and carpus (7.1\%) (von Rechenberg et al. 1998). Radiographs are routinely used for the diagnosis of SCLs and typically show a dome-shaped or round to oval subchondral lucency with a variable surrounding sclerotic rim. Unfortunately, radiographs are not always diagnostic in horses with SCLs because of summation of opacities and complex anatomical features. A change in bone density of at least $30-50 \%$ is required for the radiographic identification of osseous changes (Konde 1998). Therefore, the exact location and morphology of SCLs may not be fully assessable and smaller SCLs may be even missed radiographically. Additional findings such as fissures, osteoarthritis (OA) of the affected joint or periostitis have also been reported to be overlooked on radiographs; however, they represent important concurrent findings of SCLs influencing therapy and prognosis to a major degree (Hanson et al. 1996, Rijkenhuizen et al. 2005, Del Chicca et al. 2008).

Computed tomography $(\mathrm{CT})$ is the most appropriate imaging modality for detailed imaging of normal bone and detection of bony disorders without superimposition of other structures
(Barbee et al. 1987, Peterson and Bowman 1988). A few case series and case reports documented the usefulness of CT for the detection of occult SCLs and associated findings (Barbee et al. 1987, Hanson et al. 1996, Garcia-Lopez et al. 2004, Rijkenhuizen et al. 2005). However, so far, no study substantially compared the SCL visibility and features of SCLs in CT versus radiography. Therefore, we hypothesized that CT has a superior diagnostic value for the assessment of the features of equine SCLs, especially the visibility and the continuity of the subchondral bone. Further, we compared and assessed intermodality agreement of radiographic and CT characteristics of SCLs in equine limbs.

\section{Materials and Methods}

Horses which were presented at our hospital between 2005-2014 were included in the present retrospective study if a) a single SCL or multiple SCLs were diagnosed in the metacarpo- (MCP), metatarsophalangeal (MTP), proximal (PIP) or distal interphalangeal (DIP) joint or the radial carpal bone (RCB) with $C T$, and b) standard radiographs of the affected region were also available. Horses represented either outpatients scheduled for a lameness examination or referral cases with a preceding lameness work-up of the referral veterinarian. 


\section{Radiography}

All radiographic studies were performed with a digital system (FCR Profect CS, Fujifilm, Switzerland, Zurich) at the Clinic for Diagnostic Imaging, Vetsuisse Faculty of Zurich, Switzerland. In the MCP, MTP and PIP joint, 4 views were obtained (lateromedial, dorsal $12^{\circ}$ proximal-palmarodistal/plantarodistal, dorsal $45^{\circ}$ lateral-palmaromedial/plantaromedial and dorsal $45^{\circ}$ medial-palmarolateral/plantarolateral oblique). The same projections were acquired in the carpus, except for a horizontal $\left(0^{\circ}\right.$ degree) dorsopalmar $(\mathrm{dp})$ view. In the DIP joint, a lateromedial and dorsal $60^{\circ}$ proximal- palmarodistal/plantarodistal view was obtained only. Contrast arthrography was not performed in any horse.

\section{Computed tomography}

Under general anesthesia, helical CT was performed in all affected limbs with a 40-slice scanner (Somatom Sensation Open, Siemens Medical Solutions, Zurich, Switzerland). Settings included $120 \mathrm{KV}, 100 \mathrm{mAs}$, 1s tube rotation, a pitch of $0.65,2 \mathrm{~mm}$ slice collimation with an increment of $2 \mathrm{~mm}$ reconstructed to $0.75 \mathrm{~mm}$ images applying a medium-frequency image reconstruction algorithm (soft tissue) and a high-frequency image reconstruction algorithm (bone), respectively.

\section{Assessment of radiographs and CT images}

Dedicated software was used for reviewing the radiographic and CT images (OsiriX Open SourceTM 5.0.2, OsiriX Foundation, Geneva, Switzerland). For evaluation of the CT images, multiplanar imaging (dorsal, transverse, sagittal planes) and a bone window (window width, 3000 Hounsfield units; window level, 500 Hounsfield units) were applied. Because of the retrospective study design, markers were not used on radiographs and radiographic measurements could not be corrected for magnification. Three of the authors (SS, MJ, PK), including an equine surgeon (Dipl. ECVS) and a radiologist (Dipl. ECVDI) scored CT and radiographic images independently; panellists were blinded for the location of the SCLs. If results were diverging between panellists, these cases were discussed with all observers for a final consensus.

The following criteria were evaluated in each $\mathrm{SCL}$ on both, radiographic and CT images: location (3 subgroups: proximal, distal; medial, lateral, midsagittal; dorsal, central, palmar/plantar), shape (round, oval, half-circle, pear-shaped, conical, shapeless), homogeneity (homogeneous, inhomogeneous), maximum cross-sectional area (dp view or dorsal plane, respectively), continuity of the subchondral bone (continuous, discontinuous), peripheral sclerosis (none, mild, moderate, severe), presence of a fissure (yes, no), as well as osteoarthritis (OA) or periostitis (none, mild, moderate, severe). A fissure was defined as a short, thin radiolucent line (crack) extending from the subchondral bone into but not through the bone. The presence of vascular channels (yes, no) was only assessed on CT images. Vascular channels represented small cylindrical tracts and appeared as circular, hypoattenuating structures when evaluated on a plane perpendicular to the longitudinal axis of the vascular channels (Valdes-Martinez 2012).
Statistical analysis

Data were analysed with the SPSS statistical program (IBM SPSS Statistics, Version 19, Chicago, Illinois, USA). Because not all SCLs were visible on radiographs, the dependent variable radiographic visibility (yes/no) was defined. The 95\% confidence interval $(95 \% \mathrm{Cl})$ according to Wilson procedure and a z-test for proportions were computed for radiographic visibility. Association between two discrete variables was assessed by a Chi²-test. The Mann-Whitney-test was applied to compare median maximal cross-sectional area between radiographic visibility groups. Pearson correlation $\left(r^{2}\right)$ was computed for the association between radiographic and CT maximal cross-sectional area. Kappa values (к) were calculated to estimate agreement between radiographic and CT criteria.

Logistic regression (Odds ratios (OR), 95\% Cl) was applied at SCL level to determine if there were certain morphologic CT characteristics present in the SCLs that made detection on radiography challenging. Due to clustering in the data set (more than one SCL per patient), data were also analysed at SCL level adjusted for clustering (Generalized Estimating Equations (GEE) methodology with exchangeable covariance structure). P-values $<0.05$ were considered statistically significant.

\section{Results}

Thirty-two horses fulfilled the inclusion criteria for the study. Animals had a mean age of $8.1 \pm 4.3$ years (range, 1 to 16 years), and there were 14 mares, 16 geldings and 2 stallions. Breeds included 24 Warmblood horses (75\%), 3 Quarter Horses (10\%), 2 ponies (6\%), and one each: Haflinger, Friesian, and Icelandic horse (9\%).

CT

In total, 42 SCLs were diagnosed in 39 joints with CT. Forelimbs (15 left and 15 right joints) were more often affected than hind limbs (7 left and 5 right joints). Twenty-two horses had a single SCL whereas 10 individuals had two SCLs: in different legs $(n=5)$, in the same joint but in a different bone $(n=3)$, or in the same leg but in a different joint $(n=2)$. Two cysts in different legs were significantly more common in Quarter Horses ( $p=0.007)$. Cystic lesions were most often seen proximal in the first phalanx $(P 1)(n=17)$ followed by 7 SCLs each: proximal in the third phalanx (P3) and distal in the third metacarpus/metatarsus (MC3/MT3). Distal P1 $(n=6)$, proximal second phalanx $(P 2, n=2)$, the central RCB $(n=2)$ and distal P2 $(n=1)$ were affected less frequently. The majority of SCLs was localized midsagittally ( $n=28,67 \%)$, whereas $9(21 \%)$ and 5 (12\%) SCLs were found medially or laterally. Further, midsagittal SCLs were significantly more frequent in front legs than in hind legs $(p=0.04)$. Within the sagittal plane, 31 SCLs were located centrally (74\%) and only 6 $(14 \%)$ were in the dorsal and 5 each, in the palmar or plantar, aspect of a bone (12\%). Warmblood horses showed significantly more often SCLs localized within the MCP or MTP joint ( $p=0.007)$ than other breeds.

There was no significant association between maximum cross-sectional area of SCLs and homogeneity $(p=0.361)$. 
OA was significantly more common in SCLs of the MCP and MTP joints $(p<0.0001)$ and if two SCLs were present within the same joint $(p=0.013)$. Periostitis was diagnosed in 13 SCLs, of which 5 cases also presented a fissure and another 4 cases exhibited a vascular channel. Vascular channels (Fig 1) were significantly more common in $\mathrm{Pl}(\mathrm{n}=7, \mathrm{p}=0.03)$.

\section{Comparison between radiography and CT}

Overall frequencies of radiographic and CT criteria are presented in Table 1. Of the 42 SCLs diagnosed by CT, 33 (79\%) SCLs were identified radiographically $(95 \% \mathrm{Cl}, 0.64$ to 0.88 ,
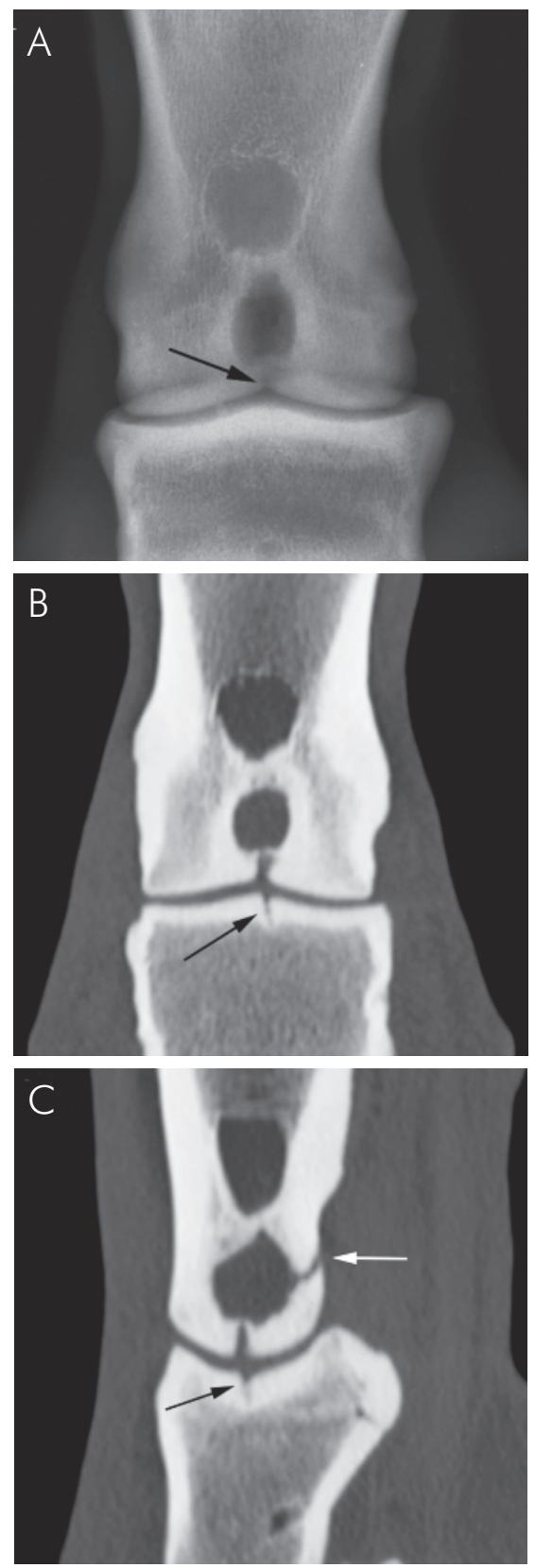

Fig 1 Dorsopalmar radiograph (A) of a left hind pastern shows a large midsagittal SCL in the distal aspect of $\mathrm{P} 1$ with moderate peripheral sclerosis and a neck-like communication to the discontinuous subchondral bone (black arrow). On dorsal (B) and sagittal (C) plane CT images, findings are confirmed and additionally, a split-like kissing lesion in the proximal aspect of P2 (black arrow) and a vascular channel to the palmar cortex of P1 (white arrow) are identified. $p=0.002)$. Of the 9 radiographically missed SCLs, 7 cases were located in the MCP or MTP joint: proximal in Pl $(n=4)$ and distal in the MC/MT3 bone $(n=3)$ (Fig 2). One each was located proximally in P2 and P3, respectively. In joints with two

Table 1 Absolute frequencies of radiographic and computed tomographic characteristics in 42 equine subchondral cystic lesions (SCLs).

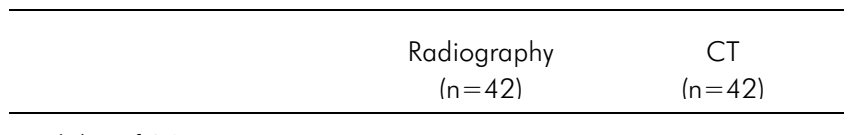

Visibility of SCL

Yes

33

42

No (missed)

9

\begin{tabular}{lcc}
\hline Shape & & \\
Round & 11 & 12 \\
Oval & 5 & 4 \\
Half-circle & 3 & 2 \\
Pear-shaped & 0 & 1 \\
Conical & 1 & 0 \\
Shapeless & 13 & 23 \\
\hline
\end{tabular}

Homogeneity

\begin{tabular}{lll} 
Homogeneous & 15 & 11 \\
Inhomogeneous & 18 & 31 \\
\hline
\end{tabular}

Continuity of SC bone

\begin{tabular}{lcc} 
Continuous & 10 & 2 \\
Discontinuous & 23 & 40 \\
\hline
\end{tabular}

Peripheral sclerosis

\begin{tabular}{lcc} 
None & 9 & 5 \\
Mild & 16 & 24 \\
Moderate & 6 & 12 \\
Severe & 2 & 1 \\
\hline Osteoarthritis & & \\
None & 24 & 20 \\
Mild & 13 & 17 \\
Moderate & 5 & 5 \\
Severe & 0 & 0 \\
\hline
\end{tabular}

\begin{tabular}{lcc}
\hline Periostitis & & \\
None & 35 & 29 \\
Mild & 4 & 8 \\
Moderate & 2 & 3 \\
Severe & 1 & 2 \\
\hline
\end{tabular}

Fissure

Yes

7

Proximal in $3^{\text {rd }}$ phalanx

$5 \quad 7$

Distal in $1^{\text {st }}$ phalanx

Proximal in $1^{\text {st }}$ phalanx

Vascular channel 
cystic lesions, the second SCL was significantly more often missed radiographically $(p=0.014)$ compared to joints with only one SCL. Further, SCLs were significantly better depicted on dorsopalmar/-plantar than on lateromedial views $(p=0.017)$.

Maximum cross-sectional area of SCLs did not significantly differ between radiographic $\left(0.5 \pm 0.48 \mathrm{~cm}^{2}\right)$ and CT measurements $\left(0.4 \pm 0.38 \mathrm{~cm}^{2}\right)(p=0.33)$ and correlation was well $\left(r^{2}=0.75, p<0.0001\right)$. A non-significant trend revealed that radiographically missed SCLs (Fig 3) were smaller in CT than SCLs diagnosed on both, radiographs and CT $(p=0.045)$ and presented with significantly less peripheral sclerosis on CT images $(p=0.023)$.
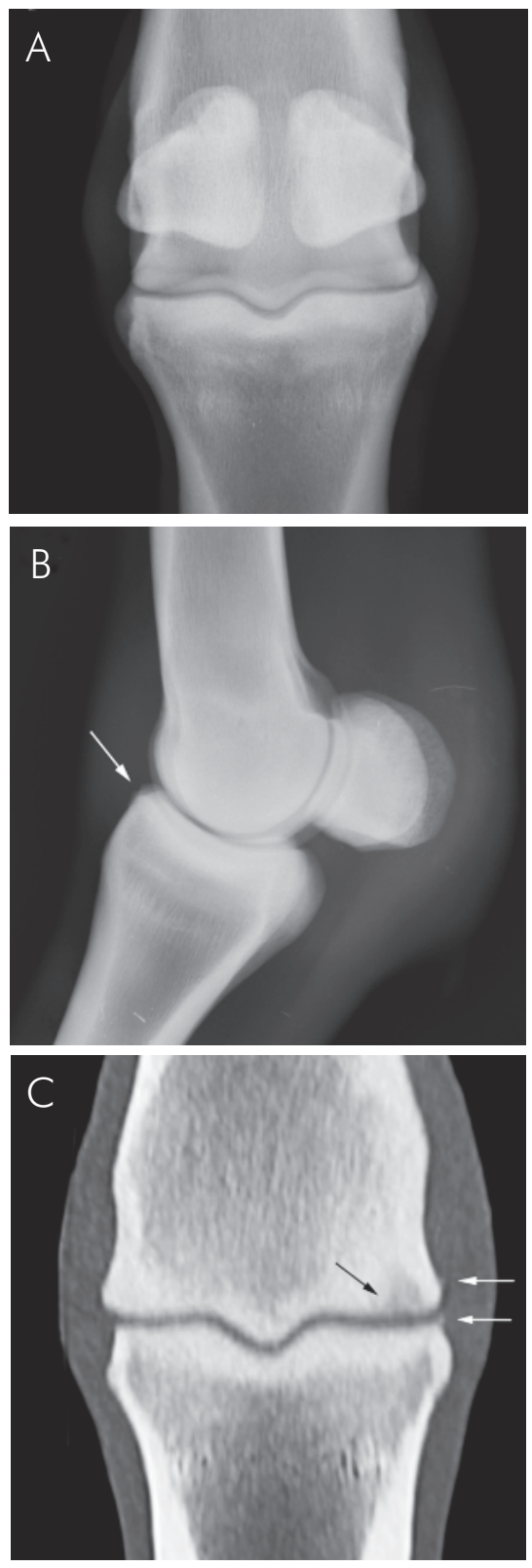

Fig. 2 Dorsopalmar (A) and lateromedial (B) radiograph of a right front fetlock show mild soft tissue swelling in the fetlock area with mild enthesophyte formation (white arrow) dorsoproximal on P1 and a markedly thickened subchondral bone of P1. The medial condyle of MC3 appears mildly flattened, however, a SCL is not present. On dorsal plane CT image (C), a large heterogeneous SCL with peripheral sclerosis and a discontinuous subchondral bone (black arrow) within the distal aspect of the medial condyle of MC3 and associated $\mathrm{OA}$ (white arrow) are identified.
A discontinuous subchondral bone was evident on CT in 40 (95\%) SCLs and was only suspected in 23 (55\%) radiographically diagnosed SCLs. Fewer cases with a fissure were diagnosed radiographically $(n=5)$ and two were determined to be vascular channels when imaged by CT (Fig 4). Due to low number of cases per group, statistics could not be performed for this criterion. Midsagittal fissure lines (7/7) and fissures in the proximal aspect of $\mathrm{P} 1$ (5/7) were significantly more common $(p=0.023$ and $p<0.0001$, respectively). Three out of 7 fissures each were located either centrally without involving any cortex or extending into the dorsal cortex. Only one fissure involved the dorsal and the palmar cortex. SCLs with fissures showed significantly more periostitis in CT $(p=0.01)$. No significant CT criteria were identified determining radiographic visibility (Table 2).

Intermodality agreement for location (proximal, distal; lateral, medial, midsagittal), $\mathrm{OA}$ and periostitis was borderline good $(\kappa=0.60-0.66)$, whereas it was borderline moderate for presence of a fissure $(\kappa=0.42)$, fair for homogeneity $(\kappa=0.35)$, and only poor for localization (dorsal, central, palmar/plantar), shape, peripheral sclerosis and continuity of the subchondral bone $(\kappa=0.06-0.18)$.
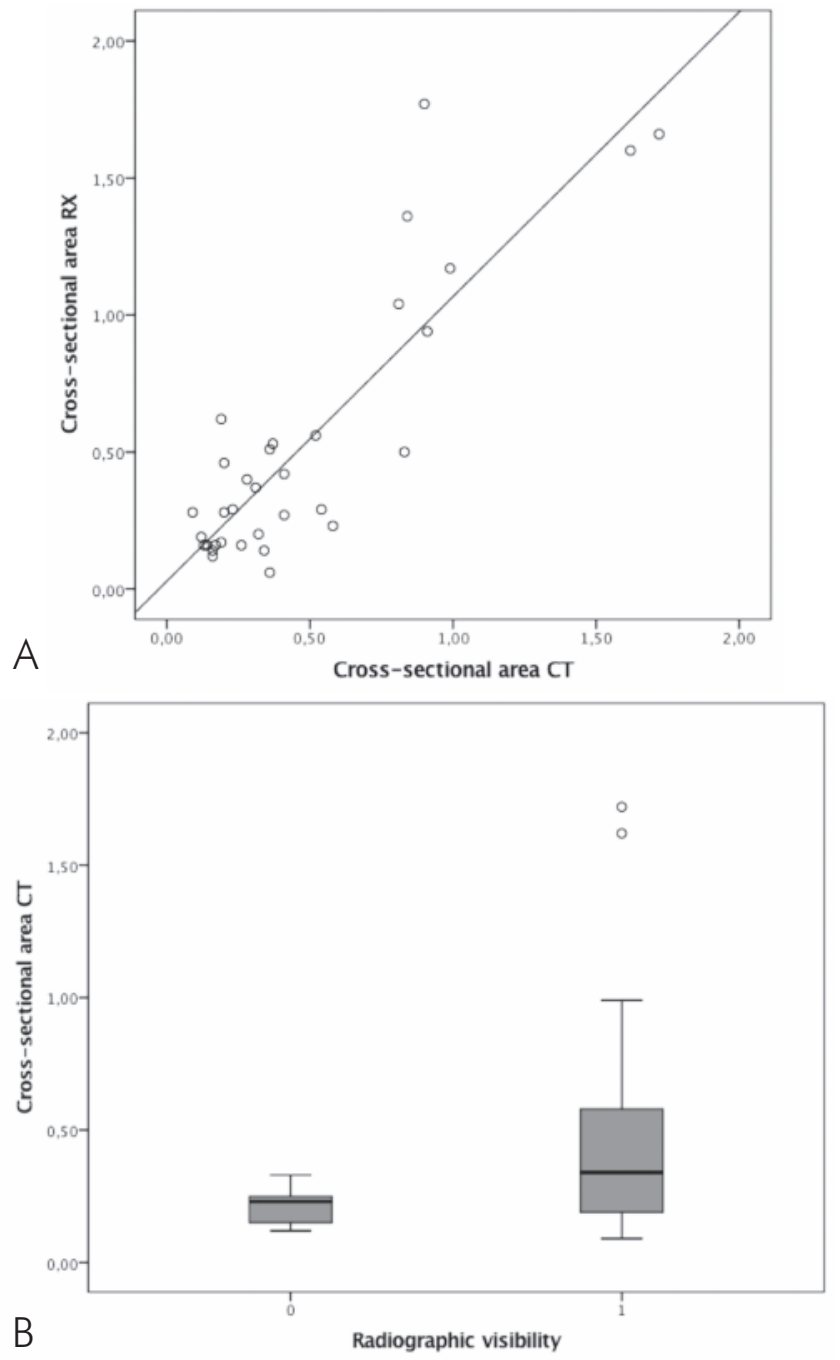

Fig. 3 Correlation between radiographic and computed tomographic (CT) cross-sectional area $\left(\mathrm{cm}^{2}, \mathrm{R} 2\right.$ Linear $\left.=0.751\right)(\mathrm{A})$. Box plot (B) represents the dependence of CT cross-sectional area $\left(\mathrm{cm}^{2}\right)$ of SCLs with respect to radiographic visibility $(0=$ no, $1=$ yes $)$. 

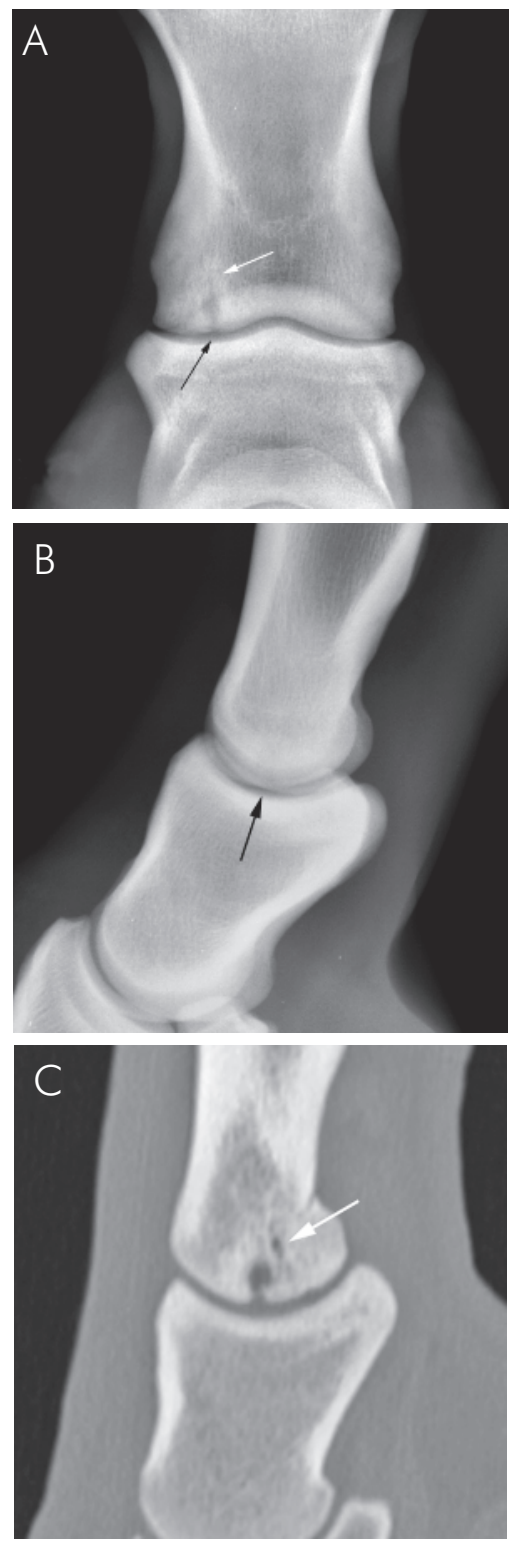

\section{Discussion}

The objective of this study was to measure the difference between and agreement of the morphology of SCLs in horses assessed on radiography versus CT. The total number of SCLs counted on $\mathrm{CT}$ was higher than with radiography supporting results of former case series reports in the veterinary literature (Barbee et al. 1987, Hanson et al. 1996, Garcia-Lopez et al. 2004). Additionally, CT was significantly better in identifying more than one SCL and, although borderline non-significant, smaller SCLs. Superiority of CT was also found for the detection of a discontinuous subchondral bone, fissures, $\mathrm{OA}$ and periostitis. Although a large number of SCLs were included in the study, sample size within subgroups for each criterion was often too small for statistical analysis. No significant CT criterion could be identified therefore, determining radiographic visibility. It was assumed by the authors that e.g. size, shape or homogeneity could have played a significant role, too. Nevertheless, intermodality agreement confirmed the different value of $C T$ versus radiography. Only for location (proximal, distal; lateral, medial, midsagittal), OA and periostitis borderline good agreement was found. Although OA is not indicative for $\mathrm{SCLs}$, it is a complication of $\mathrm{SCL}$ which also influences prognosis (Hanson et al. 1996, Rijkenhuizen et al. 2005, Del Chicca et al. 2008). Further the value for intermodality agreement was borderline moderate for presence of a fissure and even fair to poor for homogeneity, location (dorsal, central, palmar/plantar), shape, peripheral sclerosis and continuity of the subchondral bone. For a surgical approach and treatment, however, the exact location of a SCL within a bone, its relation to the articular cartilage and

— Fig. 4 Dorsoplantar (A) and lateromedial (B) radiograph of a right hind PIP joint show a large SCL with peripheral sclerosis laterodistal in P1. The subchondral bone is markedly flattened and discontinuous (black arrow). A radiolucent line was identified proximal and interpreted as a fissure (white arrow). However, on sagittal CT images (C), a complex vascular channel (white arrow) extending from the $\mathrm{SCL}$ to the lateroplantar cortex was found instead.

Table 2 Results of the ordinary and Generalized Estimating Equations (GEE) logistic regression analysis to identify computed tomographic (CT) criteria determining radiographic visibility of equine subchondral cystic lesions (SCLs).

\begin{tabular}{|c|c|c|c|c|}
\hline \multirow[t]{2}{*}{ CT criteria } & \multicolumn{2}{|c|}{ Logistic regression } & \multicolumn{2}{|c|}{$\begin{array}{l}\text { GEE Logistic regression } \\
\text { adjusted for clustering }\end{array}$} \\
\hline & $95 \%(\mathrm{OR})$ & p-value & $95 \%(O R)$ & $p$-value \\
\hline \multicolumn{5}{|l|}{ Visibility of SCL } \\
\hline Localization (proximal, distal) & $(0.06 ; 1.7)$ & 0.17 & $(0.65 ; 16.26)$ & 0.15 \\
\hline Localization (medial, lateral, midsagittal) & $(0.28 ; 6.14)$ & 0.74 & $(0.16 ; 2.74)$ & 0.57 \\
\hline Localization (dorsal, central, palmar/plantar) & $(0.23 ; 7.54)$ & 0.76 & $(0.04 ; 8.34)$ & 0.71 \\
\hline Shape & $(0.40 ; 8.82)$ & 0.42 & $(0.10 ; 2.42)$ & 0.39 \\
\hline Homogeneity & $(0.03 ; 2.61)$ & 0.27 & $(0.35 ; 33.91)$ & 0.29 \\
\hline Continuity of SC bone & $(0.23 ; 71.12)$ & 0.35 & $(0.01 ; 6.38)$ & 0.42 \\
\hline Peripheral sclerosis & $(0.11 ; 11.31)$ & 0.93 & $(0.09 ; 11.25)$ & 0.99 \\
\hline Osteoarthritis & $(0.2 ; 5.18)$ & 0.83 & $(0.20 ; 3.97)$ & 0.88 \\
\hline Periostitis & $(0.24 ; 5.54)$ & 0.86 & $(0.15 ; 4.90)$ & 0.86 \\
\hline Fissure & $(0.19 ; 17.02)$ & 0.62 & $(0.06 ; 5.99)$ & 0.66 \\
\hline
\end{tabular}


presence of a fissure are very important. In the present study, a discontinuous subchondral bone was evident in $\mathrm{CT}$ in the majority of cases. Although radiographically commonly missed, this feature seems to be a common characteristic of SCLs as recently described in SCLs in the medial femoral condyle of horses (Walker et al. 2016). Even though CT highlighted bony changes in the present study, the joint cartilage overlying a SCL and the exact nature of the subchondral bone between the cyst and the articular surface could not be assessed. In these horses, neither radiographic nor CT contrast arthrography was performed, which could have improved radiographic visibility and information about communication between a SCL and the articular surface (Verschooten and De Moor 1982, Nixon and Spencer 1990, Valdes-Martinez 2012). CT contrast arthrography technique even showed significantly higher sensitivity and specificity for diagnosis of articular cartilage defects within the equine fetlock joint than 3-Tesla magnetic resonance imaging (Hontoir et al. 2014). Nevertheless, results of CT arthrography may be disappointing because the high viscosity of the contrast medium and tissue or material present within a SCL may hamper complete filling of the cyst.

Most of the fissure lines had a midsagittal course and occurred in the proximal aspect of $\mathrm{P} 1$. The mid-sagittal groove seems to predispose the proximal phalanx to midsagittal fracture when undergoing strong torsional force from the sagittal ridge of MC3/MT3 (Nixon 2012). This supports the assumption that fissure lines occur before SCL formation. In a recent study of ten short incomplete fractures of $\mathrm{Pl}$, five fractures were accompanied by a SCL (Kümmerle et al. 2008). However, it remains unclear whether a small fissure can lead to the formation of a SCL or whether a SCL causes weakening of the bone with subsequent fissure formation (Yovich and Stashak 1989, Kümmerle et al. 2008, Dyson et al. 2011).

With CT, more than one third of the included SCLs exhibited vascular channels to the cortex. To our knowledge, vascular channels have only been described as a CT feature of SCLs in the equine stifle joint in a recent review article (Valdes-Martinez 2012). Frequencies of their occurrence have not been reported so far. In a recent pathological study in pseudocysts and true cysts in the subchondral bone of horses, dilated blood vessels were found in three different locations in true subchondral cysts: within the lesion, within the lumina of failed cartilage canals and within granulation tissue of ischemic chondronecrosis of the subjacent bone, respectively (Olstad et al. 2015). Further studies comparing CT findings with histology are needed in the future.

Dorsopalmar/plantar radiographic views were best suited for the detection of cystic lesions in the distal limb of horses but larger lesions also were seen on lateromedial or oblique views, which is in agreement with other reports (van Suntum and Hartung 1989, Deiss et al. 2001).

Another limitation has to be considered regarding this study. Standard radiographic projections were used in the present study. However, radiographic identification of SCLs and associated findings such as fissures, could have been improved with additional oblique views e.g. an elevated $45^{\circ}$ dorsopalmar/-plantar view (dorso $45^{\circ}$ proximo-palmarodistal/plantarodistal view) of the fetlock joint for the identification of a discontinuous subchondral bone between cysts in MC3/MT3 and the joint space (Hogan et al. 1997).

In conclusion, results of the present study indicate that radiography differs significantly from CT concerning the morphology of and associated findings with SCLs. CT appears a much more accurate method for the detection and the assessment of the morphology of SCLs. Especially if there is no SCL visible or if it is not possible to exactly localize the SCL via radiography alone, CT gives important additional informations for the planning of subsequent therapy and prognosis. The midsagittal proximal phalanx seems to be a frequent location for small fissures and therefore, CT represents a highly valuable diagnostic tool for the detection of these lesions. Vascular channels were an additional finding, not yet reported in the phalanges of the horse, and may aid in the clarification of the pathogenesis of SCLs. Future studies in a larger cohort of SCLs are needed to investigate CT features in similar subgroups.

\section{References}

Barbee D. D., Allen J. R., Grant B. D. (1987) Detection by computed tomography of occult osteochondral defects in the fetlock of a horse. Equine Vet. J. 19, 556-558

Deiss E., Fürst A., Haas C, von Rechenberg B., Aver J. A. (2001) Symptomatik, Diagnostik und Therpie von 5 Pferden mit traumatischen subchondralen Knochenzysten. Wien. Tierärztl. Mschr. 88, 310-321

Del Chicca F., Kuemmerle J. M., Ossent P., Nitzl D., Fuerst A., Ohlerth S. (2008) Use of computed tomography to evaluate a fracture associated with a subchondral pedal bone cyst in a horse. Equine Vet. Educ. 20, 515-519

Dyson S., Nagy A., Murray R. (2011) Clinical and diagnostic imaging findings in horses with subchondral bone trauma of the sagittal groove of the proximal phalanx. Vet. Radiol. Ultrasound 52, 596-604

Fürst A., Kaegi B., von Rechenberg B., J. A. Aver (1997) Die Behandlung von 5 Pferden mit subchondralen zystoiden Defekten im Fesselbein. Pferdeheilkunde 13, 147-161

Garcia-Lopez J. M., Kirker-Head C. A. (2004) Occult subchondral osseous cyst-like lesions of the equine tarsocrural joint. Vet. Surg. 33, 557-564

Hanson J. A., Seeherman H. J., Kirker-Head C. A., O'Callaghan M. W. (1996) The role of computed tomography in evaluation of subchondral osseous lesions in seven horses with chronic synovitis. Equine Vet. J. 28, 480-488

Hogan P. M., Mcllwraith C. W., Honnas C. M., Watkins J. P., Bramlage L. R. (1997) Surgical treatment of subchondral cystic lesions of the third metacarpal bone: results in 15 horses (1986-1994). Equine Vet. J. 29, 477-482

Hontoir F., Nisolle J-F., Meurisse H., Simon V., Tallier M., Vanderstricht R., Antoine N., Piret J., Clegg P., Vandeweerd J-M. (2014) A comparison of 3-T magnetic resonance imaging and computed tomography arthrography to identify structural cartilage defects of the fetlock joint in the horse. Vet. J. 199, 115-122

Konde L. J. (1998) Aggressive versus nonaggressive bone lesions, Thrall D.E. (ed): Textbook of veterinary diagnostic radiology (ed 3)., W.B. Saunders Company, Philadelphia, pp 37-43.

Kümmerle J. M., Auer J. A., Rademacher N., Lischer C., BettschartWolfensberger R., Fürst A. (2008) Short incomplete sagittal fractures of the proximal phalanx in ten horses not used for racing. Vet Surg. 37, 193-200

Nixon A. J., Spencer C. P. (1990) Arthrography of the equine shoulder joint. Equine Vet. J. 22, 107-113

Nixon A. J. (2012) Phalanges and the Metacarpophalangeal and Metatarsophalangeal Joints, In: Equine Surgery, Aver J. A. and Stick J. A., Elsevier, St. Lois, 1300-1324 
Olstad K., Ostevik L., Carlson C. S., Ekman S. (2015) Osteochondrosis Can Lead to Formation of Pseudocysts and True Cysts in the Subchondral Bone of Horses. Vet. Pathol. 52, 862-872

Peterson P. R., Bowman K. F. (1988) Computed Tomographic Anatomy of the Distal Extremity of the Horse. Vet. Radiol. Ultrasound 29, $147-156$

Rijkenhuizen A. B. M., van den Top G. B., van den Belt A. J. (2005) The role of computer tomography in the surgical management of cystic lesions. Pferdeheilkunde 21, 317-321

Valdes-Martinez A. (2012) Computed tomographic arthrography of the equine stifle joint. Vet. Clin. North Am. Equine Pract. 28, 583-598

van Suntum M, Hartung K. (1989) Zur Erkennbarkeit subchondraler zystoider Defekte an den distalen Extremitätengelenken des Pferdes. Tierärztl. Prax. 17, 79-83

Verschooten F., De Moor A. (1982) Subchondral cystic and related lesions affecting the equine pedal bone and stifle. Equine Vet. J. 14, 47-54

von Rechenberg B., Mcllwraith C. W., Auer J. A. (1998) Cystic Bone Lesions in Horses and Humans: A Comparative Review. Vet. Comp. Orthop. Traumatol. 11, 8-18

Walker W. T., Silverberg J. L., Kawcak C. E., Bradley B. N., Fortier L. A. (2016) Morphological characteristics of subchondral bone cysts in medial femoral condyles of adult horses as determined by computed tomography. Am. J. Vet. Res. 77, 265-274

Yovich J. V., Stashak T. S. (1989) Subchondral osseous cyst formation after an intra-articular fracture in a filly. Equine Vet. J. 21, 72-74

Erweiterte Zusammenfassung

\section{Computertomotgraphische versus radiologische Erfas- sung der Sichtbarkeit sowie Charakteristika von sub- chondralen Knochenzysten der Gliedmaße beim Pferd}

Subchondrale Knochenzysten (SCLs) kommen beim Pferd relativ häufig vor und sie werden üblicherweise mit Hilfe der Radiographie diagnostiziert. Mit dieser Studie sollen die Eigenschaften subchondraler Knochenzysten (SCLs) der Gliedmaße des Pferdes radiologisch sowie computertomographisch verglichen werden. Dabei wurde angenommen, dass die Computertomographie (CT) für die Beurteilung der Sichtbarkeit sowie der Gelenksverbindung von SCLs besser als die digitale Radiographie geeignet ist.

Einbezogen wurden Pferde, die mit einer Lahmheit in Folge einer oder zwei, mittels CT diagnostizierten SCLs, an der Pferdeklinik vorgestellt wurden. Es wurden lediglich Pferde mit SCLs, lokalisiert im Os carpi radiale, im Röhrbein, im Fessel-, Kron- sowie Hufbein, in die Studie eingeschlossen. Alle Pferde wiesen vorgängig eine Röntgenstudie von der betroffenen Gliedmaße und des betroffenen Knochens auf. Die SCLs wurden radiologisch sowie computertomographisch auf folgende Kriterien evaluiert: Lokalisation (3 Untergruppen: proximal, distal; medial, lateral, midsagittal; dorsal, zentral, palmar/plantar), Größe der Fläche (gemessen in der dorsopalmaren Aufnahme sowie in der Dorsalebene, in welcher die Zyste die maximale Fläche aufwies), Form (rund, oval, halbkreis, birnenartig, konisch, formlos), Homogenität (homogen, inhomogen), Kontinuität des subchondralen Knochens (defekt, intakt), periphere Sklerose (keine, leichtgradige, mittelgradige, hochgradige) sowie das Vorhandensein einer Fissur (ja, nein), Osteoarthrose (OA) und periostalen Reaktionen (PR) (keine, leichtgradige, mittelgradige, hochgradige). Das Vorhandensein sogenannter Blutgefäßkanälen wurde lediglich mittels Computertomographie beurteilt. Diese stellten sich als feine, zylindrische Gänge dar, welche bei der Beurteilung in einer zur Längsachse des Gefäßkanales stehenden Ebene als zirkuläre, hypo- attenuierende Strukturen gesehen werden konnten. Die insgesamt 42 SCLs waren in 39 Gelenken lokalisiert. Dabei war das Fesselbein $(n=17)$ am häufigsten betroffen. Das proximale Hufbein und das distale Röhrbein wiesen je $7 \mathrm{SCLs}$ auf. Das distale Fesselbein $(n=6)$, das proximale Kronbein $(n=2)$, das Os carpi radiale $(n=2)$ sowie das distale Kronbein $(n=1)$ waren deutlich weniger häufig betroffen. Die Mehrheit der SCLs waren midsagittal lokalisiert $(n=28,67 \%)$ und lediglich $9(21 \%)$ sowie $5(12 \%)$ befanden sich medial oder lateral. In der sagittalen Ebene konnten die SCLs mehrheitlich zentral $(n=31,74 \%)$ und seltener dorsal $(n=6,14 \%)$ oder palmar respektive plantar (je $n=5,12 \%$ ) lokalisiert werden. OA konnte signifikant häufiger bei Fesselgelenkszysten $(P<0,0001)$ sowie in Gelenken, die zwei SCLs aufwiesen $(p=0,013)$, diagnostiziert werden. Die radiologische Sichtbarkeit der Zysten, welche mittels CT diagnostiziert wurde, betrug $79 \%(95 \% \mathrm{Cl}$ : 0,64 bis 0,88). In Gelenken mit zwei SCLs, konnte die zweite $\mathrm{SCLs}$ radiologisch öfters nicht gesehen werden, als in Gelenken, die nur eine Zyste enthielten $(p=0,014)$. Von den neun Zysten, welche radiologisch nicht diagnostiziert werden konnten, waren sieben Fesselgelenkszysten und lediglich je eine Hufsowie Krongelenkszyste enthalten. Die größte Fläche der Zysten war nicht signifikant unterschiedlich bei den radiologischen $\left(0.5 \pm 0.48 \mathrm{~cm}^{2}\right) \quad$ sowie computertomographischen $\left(0.4 \pm 0.38 \mathrm{~cm}^{2}\right)$ Messungen $(p=0.33)$. Es konnte jedoch ein nicht-signifikanter Trend gesehen werden, dass radiologisch verpasste Zysten im CT in der Fläche kleiner waren als SCLs, welche mit beiden Modalitäten diagnostiziert werden konnten $(p=0,045)$. Ein defekter, subchondraler Knochen konnte mittels CT in 40 von 42 SCLs gesehen werden, wobei dies bei den radiologisch sichtbaren SCLs in nur 23 von 33 Zysten vermutet werden konnte. Mittels CT konnten feine Fissuren deutlich häufiger diagnostiziert werden und in $16 \mathrm{SCLs}$ konnten Blutgefässkanäle dargestellt werden. SCLs, welche mit einer Fissur assoziiert waren, zeigten im CT signifikant stärkere Grade an periostalen Reaktionen $(p=0,01)$. Röntgenologisch nicht darstellbare Zysten haben im CT deutlich weniger peripher Sklerose gezeigt $(p=0,023)$. Die intermodale Übereinstimmung war grenzwertig gut $(\kappa=0,60-0,66)$ für die Lokalisation der SCLs (proximal, distal; lateral, medial, midsagittal), die $\mathrm{OA}$ und PR, jedoch grenzwertig moderat für das Vorkommen einer Fissur $(\kappa=0,42)$, mäßig für die Homogenität $(\kappa=0,35)$, und schlecht für die Lokalisation (dorsal, zentral, palmar/plantar), die Form, periphere Sklerose und Kontinuität des subchondralen Knochens $(\kappa=0,06-0,18)$.

Diese Studie konnte die Vorteile der Computertomographie gegenüber der digitalen Radiographie für die Sichtbarkeit sowie die Beschreibung des Charakters von SCLs beim Pferd aufzeigen. Die Computertomographie scheint die genavere Methode zu sein, um SCLs zu diagnostizieren und deren Morphologie zu beschreiben. Zudem sind Blutgefäßkanäle im Zusammenhang mit SCLs beim Pferd ein häufiger Befund. Diese sind bis anhin noch nicht bei den Phalangen beim Pferd beschrieben und könnten hilfreich sein, die Pathogenese von Knochenzysten zu klären. Zukünftige Studien mit größeren Gruppen an SCLs würden benötigt, um den diagnostischen Wert der Computertomographie für die Bewertung von Zysten in ähnlichen Beurteilungsgruppen weiter zu evaluieren.

Keywords: Subchondrale Knochenzysten (SCLs), Gliedmaße beim Pferd, Computertomographie (CT), subchondraler Knochen, Fissuren, Blutgefäßkanäle 